Acta Botanica Brasilica - 31(4): 736-741. October-December 2017. doi: 10.1590/0102-33062017abb0032

\title{
Intraspecific variation in seed size and light intensity affect seed germination and initial seedling growth of a tropical shrub
}

\author{
Aniele C. R. Veloso', Priscila S. Silva', Walisson K. Siqueira', Karen L.R. Duarte', Ingrid L. V. Gomes', \\ Henrique T. Santos ${ }^{1}$ and Marcilio Fagundes ${ }^{*}$
}

Received: January 30, 2017

Accepted: May 4, 2017

\begin{abstract}
Seed germination and seedling performance are affected by environmental factors and seed traits. In this study we investigated the effects of seed size and light intensity on germinability and seedling development of Copaifera oblongifolia. A total of 225 seeds were individually weighed and sown in three germination trays composed of 75 cells each. Each tray was placed in a different germination chamber with controlled photoperiod, temperature and light intensity. Seed size showed a positive relationship with time required for seed germination, and seeds exposed to high light intensity required more time to germinate. Seed size did not affect germination percentage, but seeds sown under high light intensity had a lower germination percentage than seeds sown under low light intensity and darkness. Seedling shoot mass showed a positive relationship with seeds mass, and seedlings grown in high light intensity had greater shoot mass than seedling growth in low light intensity and darkness. Thus, seed germinability of C. oblongifolia was higher in darkness while seedlings exhibited greater development under light. Looking to explain the ability of $C$. oblongifolia to colonize open/disturbed sites, it seems possible that plowing soil can bury seeds, thereby stimulating the germination of seeds present in the seed bank.
\end{abstract}

Keywords: Cerrado, Copaifera oblongifolia, diversity conservation, dominancy, habitat invasion, seed-seedling conflict

Understanding why some plants become dominant and even form homogeneous stands inside specific habitats would help in the development of strategies for species management and conservation of species diversity (Herrera \& Laterra 2009; Gallagher et al. 2015). Several morphological (e.g. size, form, stiffness) and physiological (e.g. age, photoblastism, dormancy) attributes of seeds can interact with ecological variables (e.g. light, temperature, moisture, soil quality, seed predation) to determine the local abundance of plant species (Rojas-Aréchiga et al. 2013; Ribeiro \& Borghetti 2014; Souza \& Fagundes 2017). Thus, finding a predictable relationship between plant life history and environmental variables will help determine the ability of plants to become established and elucidate traits that allow species to become dominant in specific habitats (Murray et al. 2005; Ferreras et al. 2015; Jelbert et al. 2015).

Seed mass is an important evolutionary trait that affects seed germination, seedling performance and plant ${ }^{1}$ Laboratório de Biologia da Conservação, Departamento de Biologia Geral, Universidade Estadual de Montes Claros, 39401-089, Montes Claros,
MG, Brazil

* Corresponding author: marcilio.fagundes@gmail.com 
community organization (Yanlong et al. 2007; Herrera \& Laterra 2009; Souza \& Fagundes 2014). While smaller seeds generally germinate faster, larger seeds often have a higher germination percentage than small seeds (Cordazzo 2002). Seed size is also directly related to the amount of nutritional reserves that can be allocated to initial seedling development (Yanlong et al. 2007; Souza \& Fagundes 2014). In general, when compared to small seeds, larger seeds produce more vigorous seedlings (Gharoobi 2011; Fagundes et al. 2011). Plant species that produce larger-sized seeds are favored in predictable and more competitive habitats (Baskin \& Baskin 1998; Ferreira \& Borghetti 2004), while plant species that produce a greater number of smaller seeds have greater competitive advantage, especially in early successional habitats (Baskin \& Baskin1998; Moles \& Westoby 2006; Rojas-Aréchiga et al. 2013).

Seed size can interact with other environmental factors (e.g. light, moisture, temperature, soil quality) in determining the success of seed germination and plant recruitment among habitats (Pearson et al. 2003; Khan \& Gulzar 2003; Yanlong et al. 2007; Fagundes et al. 2011). Small seeds generally germinate better in light than in darkness, while large seeds do not exhibit a difference in germination between these two conditions (Milberg et al. 2000; Fenner \& Thompson 2005). However, some studies have shown the effect of light intensity on seed germination is variable and may be species dependent (Moles \& Westoby 2006; Onyekwelu et al. 2012). In addition, light is perhaps the main environmental factor involved in seedling survival and growth among habitats (Onyekwelu et al. 2012). The biomass of roots, stems, leaves and whole plant was found to decrease under low light intensity (Zervoudakis et al. 2012). However, because light intensity varies temporally and spatially, plants species acclimate and develop plasticity to cope with variation in light regimes. Plants characterized as sun species must have a positive response to increased light intensity while light excess can inhibit the growth of plants shade adapted (Gonçalves et al. 2005). Thus, environmental traits that are suitable for seed germination may not be ideal for seedling or adult plant development, generating a seed-seedling conflict (Moles \& Westoby 2006; Herrera \& Laterra 2009).

Copaifera oblongifolia Mart. (Fabaceae) is a heliophyte shrub species that reaches up to $2.5 \mathrm{~m}$ in height in the Brazilian Cerrado. The plants of the studied population are semideciduous with the production of new leaves from July to September. Flowering occurs from February to May and fruits ripen from August to October. Upon opening, each fruit exposes one ellipsoid seed (rarely two), which is black and shiny and partially covered by a yellow-orange aril. The species occurs in open areas such as abandoned pastures, borders of Cerrado fragments and highways. Moreover, this shrub often invades pastures and agricultural systems, becoming dominant and inhibiting the development of cultivated plants in northern Minas Gerais State (MF, personal observations). In this study we hypothesized that light intensity and seed size affect germination success and seedling performance of $C$. oblongifolia. Specifically, the following predictions of this hypothesis were tested: (i) seeds will experience greater germinability and seedlings will have greater initial growth under high light intensity, and (ii) larger seeds will have a greater germination percentage and will produce more vigorous seedlings than smaller seeds.

In order to perform germination tests, mature seeds were collected from 21 individuals of $C$. oblongifolia in an area of Cerrado vegetation ( $16^{\circ} 17^{\prime} 20^{\prime \prime}$ 'S and $44^{\circ} 09^{\prime} 02^{\prime \prime} \mathrm{W}$ ) in the municipality of Mirabela in northern Minas Gerais, Brazil, during October 2015. The region has a semi-arid climate with well-defined dry and wet seasons. The average annual temperature is $23^{\circ} \mathrm{C}$ and rainfall is about $1000 \mathrm{~mm} /$ year (Souza \& Fagundes 2017). A total of 20 well-formed seeds were haphazardly collected from each individual plant, packed in individual paper bags and weighed with an analytical scale to determine the biomass of each seed. Thus, seed mass was used as a proxy for seed size (see Souza \& Fagundes 2014). All 420 seeds collected were manually examined, with malformed seeds and those with visual signals of attack by predators or pathogens being eliminated. Finally, a set of 225 homogenous seeds (about nine to 11 seeds for each individual plant) was selected to perform the germination experiment.

The selected seeds were individually sown in three germination trays composed of 75 individual cells $(2 \mathrm{~cm}$ long, $2 \mathrm{~cm}$ wide and $3 \mathrm{~cm}$ tall) with vermiculite used as a substrate. Each tray with 75 seeds represented a specific light-intensity treatment, and was placed in its own germination chamber with the photoperiod, temperature and light intensity as follows: $\mathrm{t}_{1}=$ high light intensity, $12 \mathrm{~h} /$ light at $28^{\circ} \mathrm{C}$ and $12 \mathrm{~h} /$ dark at $28^{\circ} \mathrm{C}$, 4 fluorescent-lamp equivalent to $47.5 \mu \mathrm{mol} . \mathrm{m}^{-2} \mathrm{~s}^{-1}$ irradiation; $\mathrm{t}_{2}=$ low light intensity, $12 \mathrm{~h} /$ light at $28{ }^{\circ} \mathrm{C}$ and $12 \mathrm{~h} /$ dark at $28^{\circ} \mathrm{C}$, 2 fluorescent-lamp equivalent to $23.8 \mu \mathrm{mol} . \mathrm{m}^{-2} \mathrm{~s}^{-1}$ irradiation; and $\mathrm{t}_{3}=24 \mathrm{~h} /$ darkness at $28^{\circ} \mathrm{C}$ ). This experimental design assumed each seed with their specific mass to be a statistically independent experimental unit, thus permitting comparisons of seed germinability among treatments (see Warton \& Hui 2011; Souza \& Fagundes 2014). Before sowing, all seeds were subjected to disinfection by immersion in a $1 \%$ sodium hypochlorite solution for two minutes (Souza et al. 2015). The humidity of the germination substrate was maintained daily by adding three milliliters of distilled water to each germination cell. Seeds were monitored daily to determine the germination percentage and time to germination. Seeds were considered germinated when they exhibited primary root protrusion.

Seedlings from the germination test were used to evaluate the effects of light intensity and seed mass on biomass accumulation by seedlings. Time for seedling development was defined as the time elapsed between seed germination and the fall of the seedling cotyledons. All 
seedlings were removed from the substrate after the fall of the cotyledons to determinate their dry biomass. Seedlings were individually placed in properly identified paper bags and transferred to an air circulation oven at $60{ }^{\circ} \mathrm{C}$ for 72 hours. After this time, the dry weight of aerial portion and the root system of each seedling were determined using an analytical scale. Finally, the ratio of root:shoot biomass of all seedlings was calculated using the ratio between dry mass of the root and dry mass of the shoot.

The effects of light intensity and seed mass on time required for seed germination or germination percentage were tested using General Linear Models (GLM) followed by ANOVA. Thus, time required for seed germination or germination percentage was used as a response variable while the treatments of light intensity, seed mass and the interaction between them were the explanatory variables. Because the seed germination data is binary (germinated or not-germinated), a binomial error distribution was used in model construction (Warton \& Hui 2011). To test the effect of light intensity and seed mass on seedling vigor, different Generalized Linear Models (GLM) were constructed with total biomass, aerial biomass, root biomass or root:shoot ratio being used as response variables and treatments, seeds mass and the interaction term as the explanatory variables. All significant models that presented an explanatory variable with more than two levels were submitted to a contrast analysis to combine levels that were not significantly different, and separation of significantly different levels.

The analyses were carried out in $\mathrm{R}$ software ( $\mathrm{R}$ Core Team 2014). All models were submitted to residual analysis to check for model fit and suitability of error distribution for each response variable (Crawley 2007). The Akaike Information Criterion for small samples (AICc) was used to order explanatory variables and select the most parsimonious model. These procedures were carried out using the MuMIn package on R software (Barton 2015).

The seeds of Copaifera oblongifolia began germinating on the $12^{\text {th }}$ day and continued until the $81^{\text {st }}$ day after sowing. Light intensity, seed mass and the interaction between light intensity and seed mass affected the time required for seed germination (Tab. 1). Seed size showed a positive relationship with time required to seed germination, and seeds exposed a high light intensity required more time to germinate. However, a significant interaction term suggests that the relationship between seed size and time for germination changes according to light intensity. In fact, results of contrast analysis showed that the positive relationship between seed mass and time required to seed germination was evident only under the low light intensity treatment (Fig. 1A). Only light intensity affected seed germination percentage (Tab. 1), and seeds sown under high light intensity had a lower germination percentage than seeds subjected to low light intensity and darkness (Fig. 1B).

Table 1. Summary of minimal adequate models showing the effects of explanatory variables (light intensity and seed mass) on the variables responses (time required to seeds germination, percentage of seed germination, total mass, shoot mass, root mass and root:shoot ratio) of Copaifera oblongifolia shrubs.

\begin{tabular}{|c|c|c|c|c|c|c|}
\hline Response variables & Explicative variables & Deviance & Df from residue & Residual deviance & F-values & P-values \\
\hline Time for seed & Light intensity & 10113.6 & 184 & 22066 & 45.059 & $<0.01$ \\
germination & Seed mass & 793.9 & 183 & 21272 & 7.067 & $<0.01$ \\
& Light intensity x seed mass & 939.9 & 181 & 20332 & 4.183 & 0.016 \\
\hline Seed germination & Light intensity & 5.721 & 184 & 25.026 & 2.860 & 0.047 \\
\hline Total mass & Seed mass & 0.003 & 111 & 0.065 & 112.6 & $<0.01$ \\
& Light intensity x seed mass & 0.004 & 109 & 0.060 & 0.041 & 0.021 \\
\hline \multirow{2}{*}{ Aerial mass } & Light intensity & 0.003 & 112 & 0.093 & 4.072 & 0.019 \\
& Seed mass & 0.041 & 111 & 0.052 & 91.312 & $<0.01$ \\
\hline Root mass & Light intensity x seed mass & 0.004 & 109 & 0.048 & 4.679 & 0.011 \\
\hline Root: Shoot ratio & Light intensity x seed mass & 0.082 & 113 & 0.005 & 50.925 & $<0.01$ \\
\hline
\end{tabular}

Total mass of seedlings showed a positive relationship with seed mass and the significant interaction between light intensity and seed mass suggests that seedlings grown in low light intensity are more dependent on seed mass (Tab. 1, Fig. 2A). In fact, the results of contrast analysis showed the slope of curves to vary among light treatments indicating seed mass is a more important trait in low light intensities.

Seedling shoot mass was affected by seed mass, light intensity and the interaction between seed mass and light intensity (Tab. 1, Fig. 2B). In general, seed mass had a positive effect on seedling shoot mass, and contrast analysis revealed slope curves varied among treatments, indicating shoot mass of seedlings grown on low light intensity was more affected by seed mass. Moreover, contrast analysis also showed that seedlings grown in high light intensity exhibited greater shoot mass than seedlings grown in low light intensity and darkness.

Among all the explanatory variables tested, only seeds mass affected root mass, and seedlings from heavier seeds exhibited higher root mass (Tab. 1, Fig. 2C). Finally, the interaction between light intensity and seed mass was observed to affect the root:shoot ratio, with the root:shoot ratio of seedlings grown in darkness having a positive relationship with seed mass, while the root:shoot ratios of seedlings grown in low and high light intensity had a negative relationship with seed mass (Tab. 1, Fig. 2D). Thus, 
light intensity appears to affect resource allocation from seeds between root system and shoot.

Seeds can be classified into three groups according to their sensitivity to white light: (1) positive photoblastic, in which seeds germinate only under white light (produced principally by heliophyte plants); (2) negative photoblastic, in which seeds germinate only in the dark, with white light inhibiting germination; and (3) light insensitive, in which seeds germinate both in the dark and under white light (produced by understory plants) (Takaki 2001). Based on this classification, perhaps the most unexpected result found in this study was that seeds subjected to high light intensity had lower germinability; this is surprising because C. oblongifolia is a heliophyte species, growing only in open areas. However, other studies have also shown that seeds of some weed species have high germinability in the absence of light or after being buried in the soil for a period of time (Ohadi et al. 2010; Wang et al. 2016; Hu et al. 2017).

It is also important to highlight that seed size did not affect the germination percentage of $C$. oblongifolia seeds, but larger seeds required more time to germinate, especially under low light intensity. Seed mass is a trait that many authors have related to photoblastic response (Rojas-Aréchiga et al. 2013). In general, light requirement increases as seed mass decreases and shade tolerant species have larger seeds than open sites species (Pearson et al. 2003; Souza \& Fagundes 2014). Therefore, our results agree partially with the general prediction that larger seeds have greater germination percentage and require more time to germinate.

Another important result observed in this study was total and shoot mass of seedlings were positively related to seed mass, and seedlings grown under high light intensity also possessed greater total and aerial biomass. In general, larger seeds have a greater amount of reserves in their cotyledons that can be allocated to initial growth, resulting in more vigorous seedlings (Mendes-Rodrigues et al. 2011; Souza \& Fagundes 2014). Moreover, the greater biomass production by plants subjected to high light intensity can be easily explained on the basis of the general relationship between light radiation and photosynthesis rates (Onyekwelu et al. 2012; Leal et al. 2013). Therefore, the results observed in this study agree with our initial prediction that larger seeds would produce more vigorous seedlings and seedlings grown in darkness would have lower initial growth.

Root mass was not affected by light intensity and seedlings originating from heavier seeds produced more root mass. Thus, it is probable that photoassimilates produced during initial seedling development are drained principally for the production of aerial parts. Moreover, the significant interactive effect observed between seed mass and light intensity on root:shoot mass indicates that, under low and high light intensity, bigger seeds produce relatively more shoot mass than root mass, while smaller seeds invest more resources in the root system. In general, seedlings originating from smaller seeds must allocate a proportionally greater
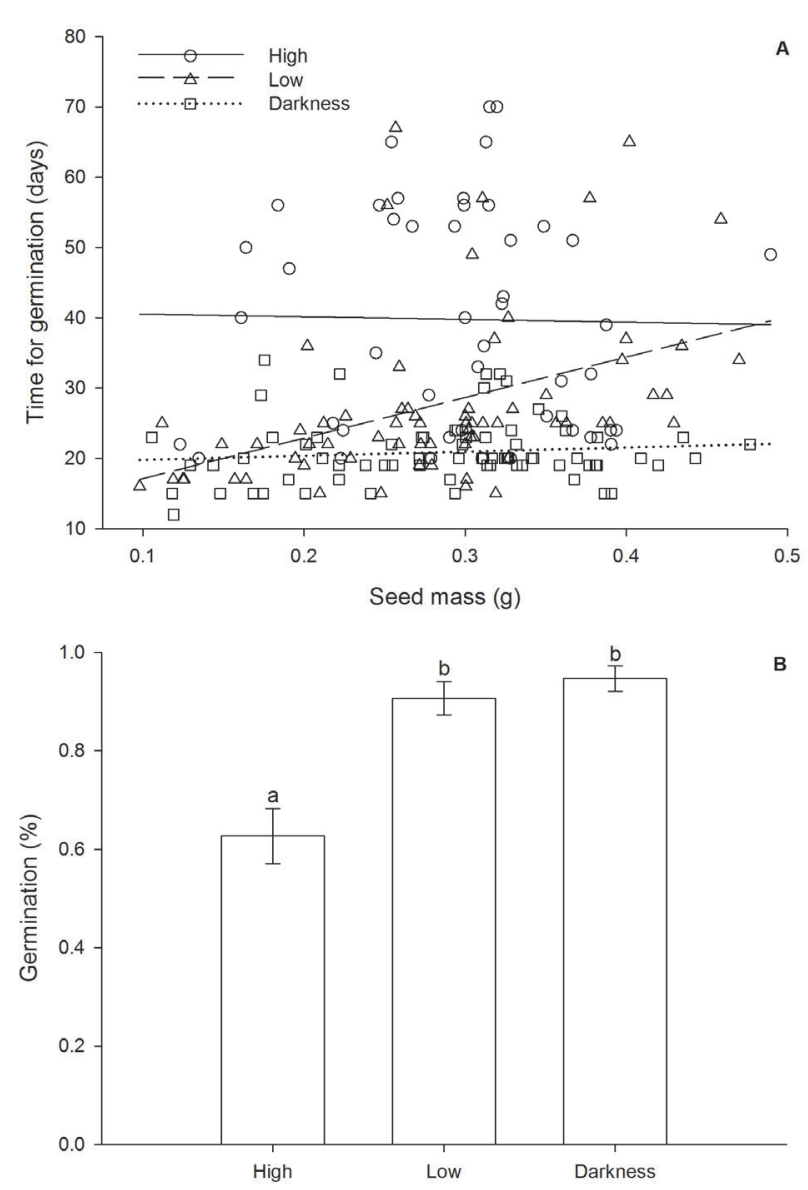

Figure 1. Seeds germnability of Copaifera oblongifolia: (A) the relationship between seeds mass and time required to seed germination under different light intensity and (B) effect of light intensity treatments on seeds germination percentage.

amount of resources to root development, resulting in a larger root system that reaches deeper into the substrate and acquiring more water and nutrients (Canadell \& Zedler 1995; Yang \& Midmore 2005).

In summary, the present study showed that while seed germinability was higher in darkness, seedlings exhibited greater development under light, and seed size positively affected seedling development. At first glance these results might seem to suggest a seed-seedling conflict. However, the apparent conflict could be solved based on the assumption that many seeds that present higher germinability in darkness should germinate better when they are buried (Pearson et al. 2003; Yanlong et al. 2007). Looking for an explanation for the relationship between the ability of $C$. oblongifolia colonize open/disturbed sites (many times invading areas that are being prepared for cultivation), and considering the results of this study, we hypothetize that human plowing of the soil can bury seeds and stimulate germination of seeds present in the seed bank. However, this hypothesis still needs to be tested under field conditions. 

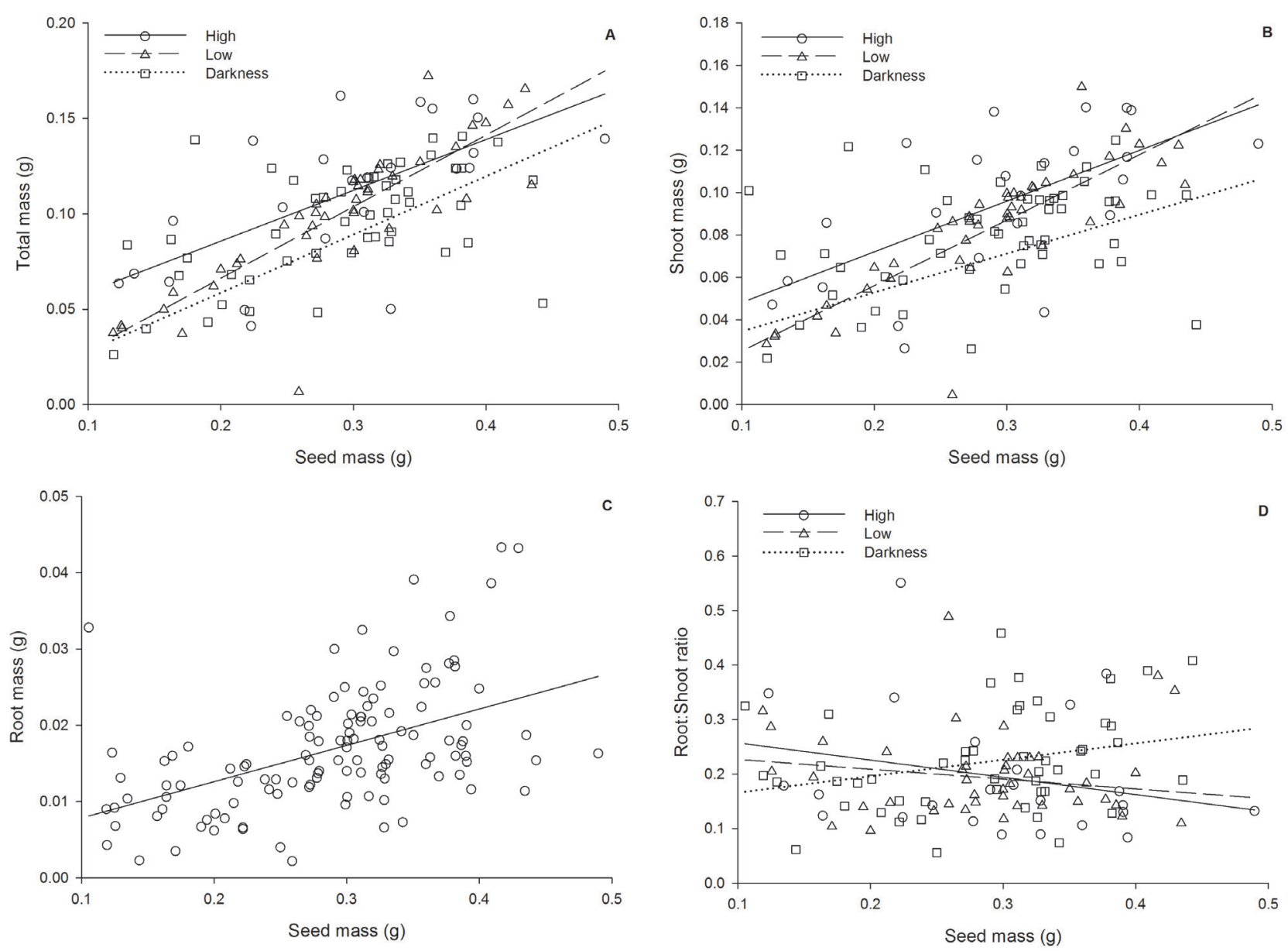

Figure 2. Relationship between seed mass and total mass (A), shoot mass (B), root mass (C) and root:shoot ratio (D) of Copaifera oblongifolia seedling growth under treatments of high and low light intensity, and darkness.

\section{Acknowledgements}

The authors thank Elio Fernandes to English language review. The study was carried out with financial support from Fundação de Amparo a Pesquisa do Estado de Minas Gerais (FAPEMIG APQ 01926.11) and Programa de Pós-Graduação Stricto Sensu em Biodiversidad e Uso dos Recursos Naurais (BURN) of the UNIMONTES. The authors also acknowledge CAPES, CNPq and FAPEMIG for research grants.

\section{References}

Bartoń K. 2015. MuMIn: Multi-Model Inference. R package version 1.15.1. 311 http://CRAN.R-project.org/package=MuMIn.

Baskin CC, Baskin M. 1998. Seeds-ecology, biogeography, and evolution of dormancy and germination. New York, Academic Press.

Canadell J, Zedler PH. 1995. Underground structures of woody plants in mediterranean ecosystems of Australia, California and Chile. In: Arroyo MTK, Zedler PH, Fox MD. (eds.) Ecology and Biogeography of mediterranean Ecosystems in Chile, California and Australia. New York, Springer-Verlag. p. 177-210.
Cordazzo CV. 2002. Effect of seed mass on germination and growth in three dominant species in southern Brazilian coastal dunes. Brazilian Journal of Biology 62: 427-435.

Crawley MJ. 2007. The R Book. New York, John Wiley and Sons.

Fagundes M, Camargos MG, Costa FV. 2011. A Qualidade do solo afeta a germinação das sementes e o desenvolvimento das plântulas de Dimorphandra mollis Benth. (Leguminosae: Mimosoidae). Acta Botanica Brasilica 25: 908-915.

Fenner M, Thompson K. 2005. The ecology of seeds. Cambridge, Cambridge University Press.

Ferreira AG, Borghetti F. 2004. Germinação: do básico ao aplicado. Porto Alegre, Editora Artmed.

Ferreras AE, Funes G, Galetto L. 2015. The role of seed germination in the invasion process of Honey locust (Gleditsia triacanthos L., Fabaceae): comparison with a native confamilial. Plant Species Biology 30: 126-136.

Gallagher RV, Randall RP, Leishman MR. 2015. Trait ifferences between naturalized and invasive plant species independent of residence time and phylogeny Conservation Biology 29: 360-369.

Gharoobi B. 2011. Effects of seed size on seedlings characteristics of five barley cultivars. Iranian Journal of Plant Physiology 1: 265-270.

Gonçalves JFC, Barreto DCS, Santos-Junior UM, Fernandes AV, Sampaio PTB, Bucheridge MS. 2005. Growth, photosynthesis and stress indicators in young rosewood plants (Aniva rosaedora Ducke) under different light intensity. Brazilian Journal of Plant Physiology 17: 325-334. 


\section{Intraspecific variation in seed size and light intensity affect seed germination and initial seedling growth of a tropical shrub}

Herrera LP, Laterra P. 2009. Do seed and microsite limitation interact with seed size in determining invasion patterns in flooding Pampa grasslands? Plant Ecology 201: 457-469.

Hu XW, Pan J, Min DD, et al. 2017. Seed dormancy and soil seedbank of the invasive weed Chenopodium hybridum in north-western China. Weed Research 57: 54-64.

Jelbert K, Stott I, McDonald RA, Hodgson D. 2015. Invasiveness of plants is predicted by size and fecundity in the native range. Ecology and Evolution 10: 1933-1943.

Khan MA, Gulzar S. 2003. Light, salinity, and temperature effects on the seed germination of perennial grasses. American Journal of Botany 90: 131-134.

Leal LC, Meiado MV, Lopes AV, Leal IR. 2013. Germination responses of the invasive Calotropis procera (Ait.) R. Br. (Apocynaceae): comparisons with seeds from two ecosystems in northeastern Brazil Anais da Academia Brasileira de Ciências 85: 1025-1034.

Mendes-Rodrigues C, Oliveira PE, Ranal MA. 2011. Seed germination and seedling growth of two Pseudobombax species (Malvaceae) with contrasting habitats from Brazilian Cerrado. Revista de Biologia Tropical 59: 1915-1925.

Milberg P, Andersson L, Thompson K. 2000. Large seeded species are less dependent on light for germination than small-seeded ones. Seed Science Research 10: 99-104.

Moles AT, Westoby M. 2006. Seed size and plant strategy across the whole life cycle. Oikos 113: 91-105.

Murray BR, Kelaher BP, Hose GC, Figueira WF, Leishman MR. 2005. A meta-analysis of the interspecific relationship between seed size and plant abundance within local communities. Oikos 101: 191-195.

Ohadi S, Mashhadi HR, Tavakkol-Afshari R, Mesgaran MB. 2010. Modelling the effect of light intensity and duration of exposure on seed germination of Phalaris minor and Poa annua. Weed Research 50: 209-217.

Onyekwelu JC, Stimm B, Mosandl R, Olusola JA. 2012. Effects of light intensities on seed germination and early growth of Chrysophyllum albidum and lrvingia gabonensis seedlings. Nigerian Journal of Forestry 42: 58-67.

Pearson T R H, Burslem DFRP, Mullins CE, Dalling JW. 2003. Functional significance of photoblastic germination in neotropical pioneer trees: a seed's eye view. Functional Ecology 17: 394-402.

R Core Team 2014. R: A language and environment for statistical computing. Vienna, R Foundation for Statistical Computing. https:// www.R-project.org/.

Ribeiro LC, Borghetti F. 2014. Comparative effects of desiccation, heat shock and high temperatures on seed germination of savanna and forest tree species. Austral Ecology 39: 267-278.

Rojas-Aréchiga M, Mandujano MC, Golubov JK. 2013. Seed size and photoblastism in species belonging to tribe Cacteae (Cactaceae). Journal of Plant Research 126: 373-386.

Souza ML, Fagundes M. 2014. Seed size as key factor in germination and seedling development of Copaifera langsdorffii (Fabaceae). American Journal of Plant Sciences 5: 2566-2573.

Souza ML, Fagundes M. 2017. Seed predation of Copaifera langsdorffii (Fabaceae): a tropical tree with supra-annual fruiting. Plant Species Biology 32: 66-73.

Souza ML, Silva DP, Fantecelle LB, Lemos Filho JP. 2015. Key factors affecting seed germination of Copaifera langsdorffii, a Neotropical tree. Acta Botanica Brasilica 29: 473-477.

Takaki M. 2001. New proposal of classification of seeds based on forms of phytochrome instead of photoblastism. Revista Brasileira de Fisiologia Vegetal 13: 104-108.

Wang H, Zhang B, Dong L, Lou Y. 2016. Seed germination ecology of catchweed bedstraw (Galium aparine). Weed Science 64: 634-641.

Warton D, Hui F. 2011. The arcsine is asinine: the analysis of proportions in ecology. Ecology 92: 3-10.

Yang Z, Midmore DJ. 2005. Modeling plant resource allocation and growth partitioning in responses to environmental heterogeneity. Ecological Modelling 181: 59-77.

Yanlong H, Mantang W, Shujun W, Yanhui Z, Tao M, Guozhen D. 2007. Seed size effect on seedling growth under different light conditions in the clonal herb ligularia virgaurea in qinghai-tibet plateau. Acta Ecologica Sinica 27: 3091-3108.

Zervoudakis G, Salahas G, Kaspiri G, Konstantopoulou E. 2012. Influence of Light Intensity on Growth and Physiological Characteristics of Common Sage (Salvia officinalis L.). Brazilian Archives of Biology and Technology 55: 89-95. 